\title{
Analysis Of Effectiveness Of Online Learning Pandemic Covid-19 In Prosthetic Orthotic Major In Polkesta
}

\author{
Nur Rachmat ${ }^{1^{*}}$ \\ ${ }^{1}$ Department of Orthotic Prosthetics, Poltekkes Kemenkes Surakarta \\ *Email: nurrachmat@gmail.com
}

\begin{abstract}
Background: Prosthetic Orthotics Major in Polkesta conducts online lectures in order to support government efforts in the even semester 2019/2020, starting from March 2020 until the end of the even semester. Several online applications are used in support of online lectures. This study was conducted to analyze the effectiveness of online learning during the covid-19 pandemic in the orthotic prosthetic Major in Polkesta Indonesia. Methods: This is quantitative descriptive study. This research uses survey method using online Google Form questionnaire. The population is students of Prosthetic Orthotic Major, There are 322 respondents who are willing to contribute in the research. Data obtained through filling in questions that are shared with all respondents in the form of google form. Then the collected data was analyzed and described. The components contained in the questionnaire consisted of several questions, namely (1) Do you understand online learning at the time of the Covid-19 Pandemic; (2) Do you think online learning at Prosthetic Orthotic Major Polkesta was effective; (3) Which online application is used for online learning that is effective in your opinion; (4) Which online learning model do you feel effective; (5) Types of assignments that make you understand during online learning; (6) What media do you use when implementing online learning; (7) are there any obstacles when you carry out online learning (8) What obstacles do you face when implementing learning. Results: there are 67 $\%$ of students felt less effective, $14 \%$ of students felt ineffective, $20 \%$ of students felt effective. Applications used by students and felt to be effective are Google meet, google classroom, WhatsApp Group. Learning methods using Life video conferencing are felt to be the most effective. Conclusion: Online learning process in the prosthetic orthotic major is not felt to be quite effective by students.
\end{abstract}

Keywords: covid-19, orthotic prosthetic, online learning

\section{INTRODUCTION}

Unforeseen circumstances in the form of the plague covid-19 disease have brought urgent changes in various sectors. The development of the virus is rapidly spreading throughout the world. Every day data in the world tells us of increasing coverage and impact of covid-19. Indonesia also entered in a state of national emergency. The death rate due to Corona has continued to increase since it was first announced there were people who were positively affected by the covid19 virus in early March 2020. This affected changes and policy reforms to be implemented. New policies also occur in the world of education to change learning that must come to class or a building, in this case the campus, to be enough at home. The government's recommendation to stay at home, physical and social distribution must be followed by a change in face-to-face learning mode to online (Ministry of Education of the Republic of Indonesia, 2020).

The government of Indonesia implements a policy that is Work From Home (WFH). This policy is an effort, which is applied to the community in order to be able to finish all the work at home. Education in Indonesia has become one areas affected due to pandemic covid19. With the limitation of interaction, Mr. Nadiem Makarim, Minister of Education in Indonesia also issued a policy that is to dismantle schools and replace the 
Teaching and Learning process using an online system base. (Ministry of Education of the Republic of Indonesia, 2020)

(Husamah, 2015)stated that in general, face-to-face learning has various advantages over teachers and students, including: 1. Formal discipline applied to face-to-face learning can form mental discipline; 2. Facilitating the provision of reinforcement immediately; 3. Facilitating the assessment process by teachers; 4 . Become a vehicle for learning to interact with students. Another plus is the ability of socialization between lecturers / tutors and students, and among peers. Not only that, lecturers can directly observe the attitudes and behavior of students in receiving material

By using this online learning system, sometimes problems arise by students and lecturers, such as unfinished subject matter delivered by the lecturer and then the lecturer replaces with other assignments. This is a complaint for students because there are more assignments given by lecturers. Various distance learning media were tried and used. The tools that can be used as online learning media include: google classroom, Google Form, whatsapp group and other media. Online learning in the Prosthetic Orthotic Major Poltekkes Kemenkes Surakarta (Polkesta) began to be carried out since March 2020. Therefore researcher is interested in conducting research on Analysis of the Effectiveness of Online Learning Pandemic Covid-19 in Prosthetic Orthotic Department of Polkesta.

\section{METHODS}

This research is a quantitative descriptive study using survey methods conducted online (Sugiyono, 2017). Primary data collection was carried out by distributing Google form questionnaires online to 322 students of Prosthetic Orthotic Major Polkesta. Data obtained through filling in questions that are shared with all respondents in the form of google form. Then the collected data was analyzed and described.

The components contained in the questionnaire consisted of several questions, namely (1) Do you understand online learning at the time of the Covid-19 Pandemic; (2) Do you think online learning at Prosthetic Orthotic Major Polkesta was effective; (3) Which online application is used for online learning that is effective in your opinion; (4) Which online learning model do you feel effective; (5) Types of assignments that make you understand during online learning; (6) What media do you use when implementing online learning; (7) are there any obstacles when you carry out online learning (8) What obstacles do you face when implementing learning

\section{RESULTS}

This research was conducted in June 2020 at the Department of Prosthetic Orthotic, Health Polytechnic Surakarta Ministry of Health Indonesia, which is known as POLKESTA. The population is students of Prosthetic Orthotic Major; there are 322 respondents who are willing to participate in the research. Google form questioner is distributed online to student class groups. Respondents who have participated are 322 students. Respondents consisted of 152 student Diploma 3 Prosthetic Orthotic Students, and 170 student Diploma 4 Prosthetic Orthotic Students as shown in Figure 1 


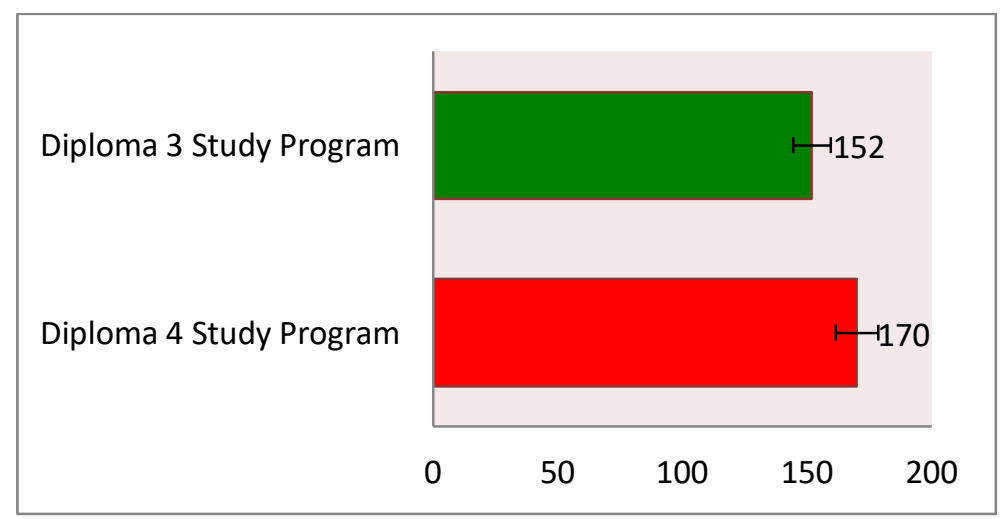

Figure 1. Distribution of Respondents by Study Program

The respondents consisted of 152 Students, and 53\% Diploma 4 Prosthetic Diploma $\quad 47 \% \quad$ Prosthetic Orthotic Orthotic Students as shown in Figure 2.

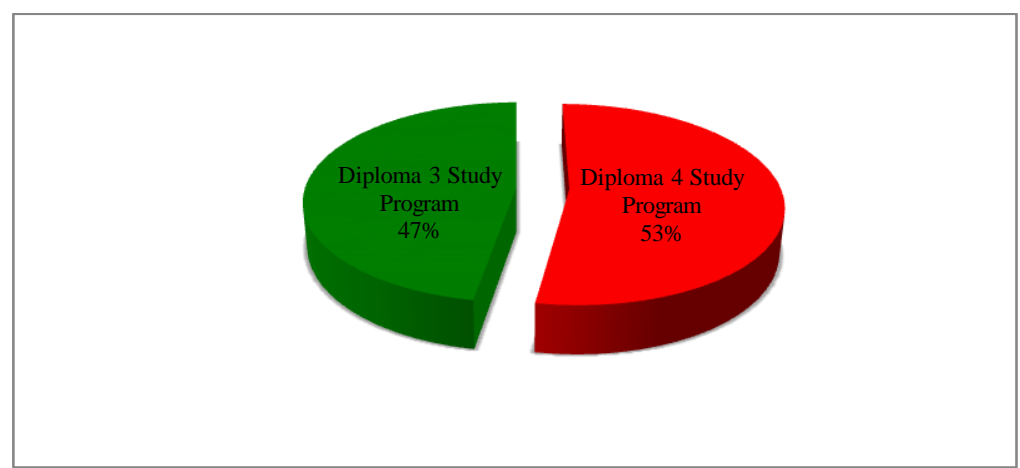

Figure 2. Distribution of Respondents by Study Program with Percentage

Respondents consisted of 38 are 46 is Diploma 3, 42 is Diploma 4. it is students of Diploma 4 in semester 8. It is consist 113 students in semester 2 which consist 83 students in semester 6, which are 63 is Diploma 3, 50 is Diploma 4, as are 43 is Diploma 3, 40 is Diploma 4. It is shown in Figure 3 consist of 88 students in semester 4 which

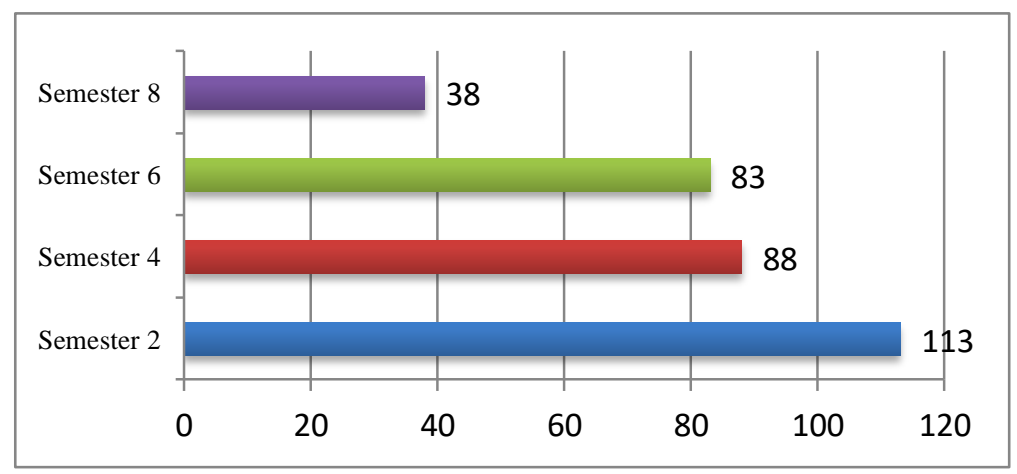

Figure 3. Distribution of Respondent by Semester

The respondents consisted of 1 students 26 years old $(0,31 \%), 2$ students 23 years 
old $(1,24 \%), 34$ students 22 years old $(10,56 \%), \quad 60$ students 21 years old $(18,63 \%), \quad 102$ students 20 years old $(31,68 \%), \quad 94$ students 19 years old
$(8,39 \%), \quad 27$ students 18 years old $(8,39 \%)$, as shown in Table 1

Table 1. Distribution Of Respondent By Age $(n=322)$

\begin{tabular}{lcc}
\hline Age & F & \% \\
\hline Age 26 & 1 & $0,31 \%$ \\
Age 23 & 4 & $1,24 \%$ \\
Age 22 & 34 & $10,56 \%$ \\
Age 21 & 60 & $18,63 \%$ \\
Age 20 & 102 & $31,68 \%$ \\
Age 19 & 94 & $29,19 \%$ \\
Age 18 & 27 & $8,39 \%$ \\
\hline Total & $\mathbf{3 2 2}$ & $\mathbf{1 0 0 , 0 0 \%}$
\end{tabular}

The respondents consisted of 79 Males students (25\%). 243 Female students (75\%) as shown in Table 2.

Table 2. Distribution Of Respomdet By Gender

\begin{tabular}{lcc}
\hline Gender & F & \% \\
\hline Male & 79 & $25 \%$ \\
Female & 243 & $75 \%$ \\
\hline Total & $\mathbf{3 2 2}$ & $\mathbf{1 0 0 \%}$ \\
\hline
\end{tabular}

Online learning conditions discussed Table 3 explains that as many as 111 of consist of understanding online learning, students $(34,47 \%)$ did understand online effectiveness of online learning, learning, students who Not Really applications used online learning, online understand online learning were 192 learning models, types of assignments in Students $(59 \%)$ and there were 18 online learning, online learning media, students $(5,59 \%)$ who did not understand constraints of online learning during the online learning during the Covid-19 Covid-19 pandemic.

The results of this study note that respondents answered varied questions.

Table 3. Understanding Of Online Learning During The Covid -19 Pandemic

\begin{tabular}{ccc}
\hline Description & $\mathbf{F}$ & $\mathbf{\%}$ \\
\hline Understand & 111 & $34,47 \%$ \\
Not Really Understand & 193 & $59,94 \%$ \\
Do Not Understand & 18 & $5,59 \%$ \\
\hline Total & $\mathbf{3 2 2}$ & $\mathbf{1 0 0 , 0 0 \%}$ \\
\hline Based on the Table 4 that online & while students who felt effective with \\
learning during the Covid-19 pandemic & online learning were 63 students (20\%) \\
was less effective are 215 students (67\%), and 44 of students (14\%) felt online
\end{tabular}


learning during the Covid pandemic -19 is ineffective.

Table 4. Effectiveness Of Online Learning During The Covid-19 Pandemic

\begin{tabular}{lcc}
\hline Description & F & \% \\
\hline Effective & 63 & $20 \%$ \\
Less-effective & 215 & $67 \%$ \\
Ineffective & 44 & $14 \%$ \\
\hline Total & $\mathbf{3 2 2}$ & $\mathbf{1 0 0 \%}$ \\
\hline Effective online learning uses & Group According to 82 students (25.47\%), \\
several learning applications namely & Zoom 34 Students (10.56\%), Youtube \\
Google Meet according to 101 students & according to 14 students (4.35\%) and \\
(31.37\%), Google Class Room according & Elearning Polkesta according to 4 students \\
to 87 students (27.02\%), WhatsApp & $(0.93 \%)$ as shown in table 5.
\end{tabular}

Table 5. Effective Applications for Online Learning During The Covid-19 Pandemic

\begin{tabular}{lcc}
\hline Application & F & \% \\
\hline Google Meet & 101 & $31,37 \%$ \\
Google Class Room & 87 & $27,02 \%$ \\
Whats App Group & 82 & $25,47 \%$ \\
zoom & 34 & $10,56 \%$ \\
Youtube & 14 & $4,35 \%$ \\
Elearning Polkesta & 4 & $0,93 \%$ \\
\hline Total & $\mathbf{3 2 2}$ & $\mathbf{1 0 0 , 0 0 \%}$ \\
\hline
\end{tabular}

Effective online learning also by Live Video Conference, the number
besides using applications also uses one selected by students so that learning several learning models. There are 4 becomes effective is $40.37 \%$, then learning models used by the Department followed by Video Recording of $29.19 \%$, of Prosthetic Orthotic to support online and the 3rd is a learning model with learning including video conferencing, modules / books of $21.12 \%$ while the Job videos, modules / books and jobsheets. Sheet is only $9.32 \%$ as shown in table 6 .

From the 4 online learning models used

Table 6. Effective Online Learning Models During The Covid-19 Pandemic

\begin{tabular}{lcc}
\hline Description & F & \% \\
\hline Job Sheet & 30 & $9,32 \%$ \\
Live Conference & 130 & $40,37 \%$ \\
Modul / Buku & 68 & $21,12 \%$ \\
Video & 94 & $29,19 \%$ \\
\hline Total & $\mathbf{3 2 2}$ & $\mathbf{1 0 0 , 0 0 \%}$ \\
\hline
\end{tabular}

Furthermore, there are survey results Make a Poster occupies the first order of about the types of effective tasks carried $42.47 \%$ and the second order is to make out in online learning during the Covid-19 Essay question is $30.42 \%$, the type of epidemic. The types of effective tasks in assignment answering Multiple Choice online learning are the types of tasks Questions is only 18.07\%, while the type 
of task makes a paper is $9.04 \%$ as shown in table 7 .

Table 7. Types of Online Learning Assignments During The Covid-19 Pandemic

\begin{tabular}{lcc}
\hline Description & $\mathbf{F}$ & $\mathbf{\%}$ \\
\hline Make a Paper & 30 & $9,04 \%$ \\
Multiple Choice Questions & 60 & $18,07 \%$ \\
Essay question & 101 & $30,42 \%$ \\
Make a Poster & 141 & $42,47 \%$ \\
\hline Total & $\mathbf{3 3 2}$ & $\mathbf{1 0 0 , 0 0 \%}$ \\
\hline The choice of media used by & Covid-19 pandemic is 232 students \\
students for online learning during the phones (72\%), Laptops 90 students (28\%).
\end{tabular}

Table 8. Online Learning Media During The Covid-19 Pandemic

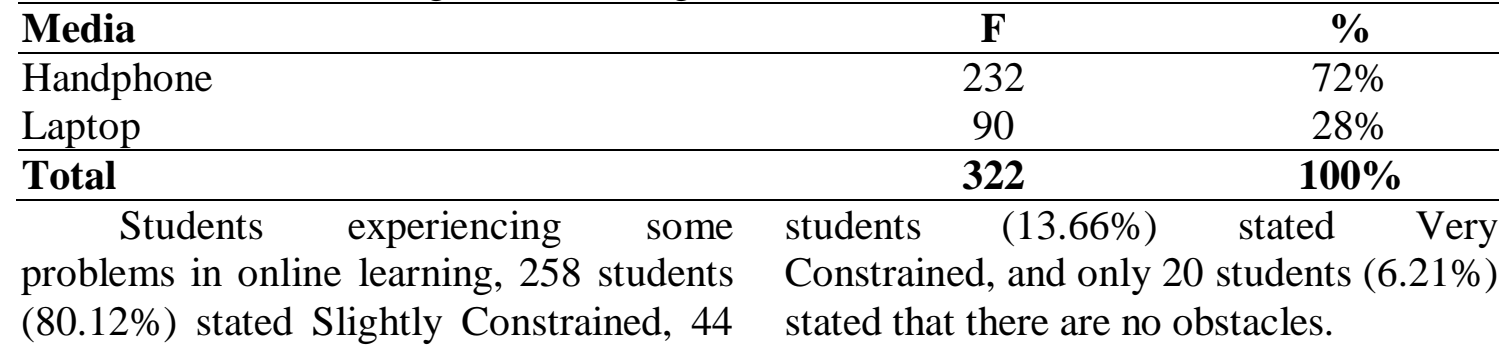

Table 9. Constraints Level in Online Learning During the Covid-19 Pandemic

\begin{tabular}{|c|c|c|}
\hline Description & $\mathbf{F}$ & $\%$ \\
\hline Very Constrained & 44 & $13,66 \%$ \\
\hline Slightly Constrained & 258 & $80,12 \%$ \\
\hline No obstacles & 20 & $6,21 \%$ \\
\hline Total & 322 & $100,00 \%$ \\
\hline
\end{tabular}

Based on Table 10 shows facility as $57,68 \%$ of students experience a slow constraints in online learning during the Internet network, while $42,32 \%$ of Covid-19 pandemic. The obstacle faced students face online learning constraints by students in online learning is as much because of limited quota.

Table 10. Facilities Constraints

\begin{tabular}{lcc}
\hline Constraint & F & \% \\
\hline Slow internet network & 184 & $57,68 \%$ \\
Limited quota & 135 & $42,32 \%$ \\
\hline Total & $\mathbf{3 1 9}$ & $\mathbf{1 0 0 , 0 0 \%}$ \\
\hline
\end{tabular}

\section{DISCUSSION}

Online learning is a solution to continue carrying out teaching and learning activities between lecturers and students, without having to meet face to face on campus. There are several other studies related to this research. E-learning is a learning model that utilizes information and communication technology facilities and distance learning 
is carried out by utilizing information technology using electronic devices, namely laptops, computers and gadgets with the use of internet, elearning, google class, whatsapp media as a means of communication and zoom applications, You Tube is the most widely used in teaching and learning.

Syarifudin (2020) conducted a study entitled "Implementation of Online Learning to Improve the Quality of Education as an Impact of Social Distancing" Online learning is learning done using the internet as a place to channel knowledge. This form of learning can be done anytime and anywhere without being bound by time and without having to meet face to face. In the era of online learning technology development is increasingly sophisticated with a variety of applications and features that make it easier for users. Time bound and done without meeting face to face are the advantages of online learning that can be utilized by educators. As is happening today, online learning is the only choice of forms of learning that can be done by educators in the event of a natural disaster or global pandemic. Indonesia applies social distance in all aspects of life including education. Therefore, online learning can be said to be the only learning choice that can be done by educators to improve the quality of learning in Indonesia (Syarifudin, 2020).

Online Learning is a continuation of Learning in the network (online) with learning patterns through the help of the internet so that there will be interaction of teaching and learning activities between students and lecturers Online learning also utilizes information technology. One of the features that will often be used by lecturers in using google classroom is create assignments that function to give assignments to students. in addition there are features that create topics that are no less interesting than other features that can be used to create lecture topics that will be discussed in a virtual classroom google classroom so students can actively participate in lectures both in regular classes conducted directly in person and in the classroom google classroom (Hapsari \& Pamungkas, 2019).

The Definition of the live conference is a seminar, presentation, teaching or workshop conducted online, face-to-face online delivered via the internet and can be attended by many people in different locations, in webinar activities a person can interact directly through images video or text (Mansyur, Purnamasari, \& Kusuma, 2019)

The key to the success of a live conference that live conference targeted at demographically suitable participants with the right message and content are a great way to build your leadership and thought values so they want to talk to you after the live conference. He also added that a webinar is considered ready to use when all moving parts and logistics have been smoothly coordinated to present interesting events with predictable results that meet or exceed participants' expectations. The students could follow and understand the material provided in the covid-19 pandemic (Agron, 2014).

This Research is in line with the research conducted by Sutrisna (2018) shows that the literacy ability of students can be seen from the use of new media, one of which is Google Classrom. This internet literacy ability is able to make students more connected to new media. Learning online with Zoom and WhatsApp is only effective for theoretical 
and theoretical and practical courses, whereas in online lecture practice and course subjects are less effective.

This Research is not in line with the research Khasanah, Pramudibyanto, \& Widuroyekti, (2020) whom conducted research under the title Education in the Covid-19 Pandemic Period, conducted with a population drawn from 100 students of the Semarang Open University, Batang District from various semesters. The results of the study showed $82 \%$ of students supported and were increasingly enthusiastic in preparing technology for a new mode of learning using webinar tutorials.

Pakpahan \& Fitriani (2020) conduct research entitled "Analysis of the Utilization of Information Technology in Distance Learning in the Middle of Corona Covid-19 Pandemic Virus" the use of information technology has a very important role in the implementation of distance learning in the midst of the corona covid-19 virus pandemic19, the learning process can work well with technical information that has been growing rapidly at this time including elearning, google class, WhatsApp, zoom and other information media and internet networks that can connect lecturers and students so that the teaching and learning process can run properly as it should even in the midst of the corona covid-19 virus pandemic.

Hidayat \& Noeraida's research (2020) found experiences about the strengths and weaknesses of online learning. The power of online learning is able to help students get material enrichment through internet access. Online classes are also more flexible, not limited by time and space. The weakness of online classes is that they are unable to build student learning motivation due to limitations in two-way communication. This also results in passive students, reduced interaction with teachers and friends. Students also assessed learning as not dynamic because neither students nor teachers could grasp the overall message, both verbal and nonverbal. The experience of the strengths and weaknesses of online learning reflects two characteristics of students (1) students who feel comfortable with online classes and (2) students who prefer to learn directly in class. The characteristics of students who are comfortable learning online tend to be passive students, limit socialization, are not too active in participating in school activities such as extracurricular activities. Meanwhile, students who choose to study face-to-face in class have the opposite characteristics, such as being friendly, like to socialize, being active in class or actively joining in school activities (Hidayat \& Noeraida 2020).

Research conducted by Sukardi \& Rozi (2019) in an effort that can be done to increase the effectiveness of the learning process is to make additional interaction extensions outside the classroom. In this case, information technology can be used for learning. The use of information technology which has the same function as conventional learning is available in online learning. The results showed: (1) the online Moodle tutorial that had been developed was declared valid, practical and effective, and (2) there were significant differences in the learning outcomes of students using the b-learning model and students using the c-learning model. The learning outcomes of students who use the blearning model are higher than students who use the c-learning method (Sukardi \& 
Rozi, 2019)

Research conducted by Darmalaksana (2020) This study aims to monitor the use of WhatsApp in mobile lectures. This research method is a type of qualitative research with literature and field studies. The results and discussion of this study include the creation of the WhatApp Group, class management, and learning achievement. The conclusion of the study is that the effective use of WhatsApp has a positive impact (Darmalaksana, 2020).

Research conducted by Nurfarini \& Sauigi (2020) shows that there is a relationship between online lectures and student interest in PAI at IAIN Samarinda of 0.975 which when interpreted by table $r$ is between $0.80-1,000$ which means that the level of the relationship is very strong or very high. . Proof of the hypothesis by testing the significance using the $\mathrm{t}$ test formula, the value obtained is $=41.4746>$ $=2.36850$ so that it is declared rejected and accepted that there is a significant influence between online lectures and the learning interest of Islamic Education students at IAIN Samarinda with a correlation coefficient $(r)=0.975$ can interpreted that the amount of the contribution of the online lecture variable to the learning interest of Islamic Education students at IAIN Samarinda was $95.06 \%$ (Nurfarini \& Sauigi 2020).

This research is shown not in line with the research conducted by Firman \& Rahayu (2020) is in the form of qualitative research which aims to obtain an overview of the implementation of online learning in the Biology Education Study Program, Faculty of Teacher Training and Education (FKIP), University of West Sulawesi (Unsulbar) as an effort to suppress the spread of covid-19 in the campus environment. The research subjects were students of the Biology Education Study Program. Data were collected by telephone interview. Data analysis was performed using the interactive analysis technique of Miles \& Huberman. The results showed that: (1) students already have the basic facilities needed to take part in online learning; (2) online learning has flexibility in its implementation and is able to encourage independent learning and motivation to be more active in learning; and (3) distance learning encourages the emergence of social distancing behavior and minimizes the appearance of student crowds so that it is considered to reduce the potential for the spread of Covid-19 in the campus environment (Firman \& Rahayu 2020).

\section{CONCLUSION AND SUGGESTION}

Based on the results of the study note that the online teaching and learning process in the prosthetic orthotic major is not felt to be quite effective by students. Applications used by students and felt to be effective are Google meet, google classroom, WhatsApp Group. Learning methods using Life video conferencing are felt to be the most effective as well as video and module books. The most types of online assignments are poster making and essay writing. Most students use the Mobile Phone media to access the online teaching and learning process. Students feel quite constrained in online learning. Problems felt by students are slow Internet network and limited quota.

\section{REFERENCE}

Agron, M. (2014). No WebinarReady TM A Step-by-Step Guide to Hosting Successful Webinars. WebAttract. 
Darmalaksana, W. (2020). WhatsApp Kuliah Mobile. Fakultas Ushuluddin UIN Sunan Gunung Djati Bandung.

Firman, F., \& Rahayu, S. (2020). Pembelajaran Online di Tengah Pandemi Covid-19. Indonesian Journal of Educational Science (IJES), 2(2), 81-89.

Hapsari, S. A., \& Pamungkas, H. (2019). Pemanfaatan Google Classroom Sebagai Media Pembelajaran Online Di Universitas Dian Nuswantoro. WACANA: Jurnal Ilmiah Ilmu Komunikasi, 18(2), 225-233. https://doi.org/10.32509/wacana.v18 i2.924

Hidayat, D., \& Noeraida, N. (2020). Pengalaman Komunikasi Siswa Melakukan Kelas Online Selama Pandemi Covid - 19. JIKE : Jurnal Ilmu Komunikasi Efek,3(2), 172182.

Husamah. (2015). Pembelajaran Bauran (Blended Learning). Jakarta: Prestasi Pustaka.

Khasanah, D. R. A. U., Pramudibyanto, H., \& Widuroyekti, B. (2020). Pendidikan Dalam Masa Pandemi Covid-19. Jurnal Sinestesia, 10(1), 41-48.

Mansyur, A. I., Purnamasari, R., \& Kusuma, R. M. (2019). Webinar As Classical Guidelines Media For Online-Based Sexual Education (Meta Analysis Of Pedagogy Online). Jurnal Bimbingan Konseling, 4(1), 26-30. https://doi.org/10.1016/j.surfcoat.20

\subsection{4}

Ministry of Education of the Republic of Indonesia. Circular Letter No. 4 of 2020 Concerning the Implementation of Education Policy in the Emergency Period Spreading of Corona Virus Disease (COVID19). , (2020).

Nurfarini H \& Saugi, W. (2020). Pengaruh Kuliah Online Terhadap Minat Belajar Mahasiswa Pendidikan Agama Islam (PAI) di IAIN Samarinda. el-Buhuth: Borneo Journal of Islamic Studies, 2(2), 121-131.

Pakpahan, R., \& Fitriani, Y. (2020). Analisa Pemanfaatan Teknologi Informasi Dalam Pembelajaran Jarak Jauh Di Tengah Pandemi Virus Corona Covid-19. Journal of Information System, Applied, Management, Accounting and Researh, 4(2), 30-36.

Sugiyono. (2017). Metode Penelitian Kuantitatif, Kualitatif dan $R \& D$. Bandung: Alfabeta.

Sukardi, S., \& Rozi, F. (2019). Pengaruh Model Pembelajaran Online Dilengkapi Dengan Tutorial Terhadap Hasil Belajar. JIPI (Jurnal Ilmiah Penelitian dan Pembelajaran Informatika), 4(2), 97-102.

Sutrisna, D. (2018). Meningkatkan Kemampuan Literasi Mahasiswa Menggunakan Google Classroom. FON: Jurnal Pendidikan Bahasa Dan Sastra Indonesia, 13(2), 69-78. https://doi.org/10.25134/fjpbsi.v13i2 
Syarifudin, A. S. (2020). Impelementasi Pembelajaran Daring Untuk Meningkatkan Mutu Pendidikan Sebagai Dampak Diterapkannya Social Distancing. Jurnal Pendidikan Bahasa Dan Sastra Indonesia Metalingua, 5(1), 31-34. https://doi.org/10.21107/metalingua. v5i1.7072 